\title{
In vitro Evaluation of Fungicides and Bioagents against Alternaria cucumerina (Ellis and Everh.) Elliott causing Alternaria Leaf Spot in Bottle Gourd
}

\author{
Aishwarya S. Kammar ${ }^{1}$, M. P. Basavarajappa ${ }^{1}$, Raghavendra K. Mesta ${ }^{1}$, \\ S. H. Ramangouda ${ }^{2}$ and Shashikanth Evoor ${ }^{3}$ \\ ${ }^{1}$ Department of Plant Pathology, ${ }^{2}$ Department of Entomology, \\ ${ }^{3}$ Department of Vegetable Science, University of Horticultural Sciences, Bagalkot, India \\ *Corresponding author
}

Keywords

Alternaria

cucumerina, in vitro

Article Info

Accepted:

20 November 2019

Available Online:

10 December 2019

\section{A B S T R A C T}

A total of fifteen fungicides and four bioagents were tested for their efficacy under in vitro conditions against Alternaria cucumerina. Among fungicides tested, propiconazole gave maximum inhibition $(100.00 \%)$ of radial mycelial growth followed by hexaconazole, captan+ hexaconozole and tebuconozole + trifloxystrobin by recording mean per cent inhibition of 98.74, 95.42 and 94.78 per cent respectively.

\section{Introduction}

Bottle gourd [Lagenaria siceraria (Mol.) Standl.] is one of the important cucurbitaceous vegetable crops, which belongs to the family Cucurbitaceae having the chromosome number $2 n=22$. In India, it is cultivated in an area of 149 thousand hectare with production of 2458 thousand metric tonnes (Anon, 2017). In Karnataka, it is cultivated in an area of 0.65 thousand hectare with production of 8.36 thousand metric tonnes (Anon, 2017). Bottle gourd is affected by a number of diseases viz., powdery mildew (Erysiphae cichoracearum), anthracnose (Colletotrichum lagenarium), Alternaria leaf spot (Alternaria cucumerina); CMV etc (Zitter et al., 1998 and Saha, 2002) produced symptoms like small circular spots, on the leaves, that rapidly increased in number and coalescing of spots, lead to blightened appearance.

Since the disease is prevalent in Karnataka and causes huge yield loss, there exists a need to find out the fungicidal molecules, which can be effective in managing the disease. Few of the biocontrol agents are also potentially capable of suppressing the pathogen 
multiplication. Thus bio control agents were also included in disease management programme. Keeping all these points in view, the present research work was undertaken on In vitro evaluation of fungicides and bioagents against Alternaria cucumerina causing Alternaria leaf spot in bottle gourd. Among the foliar diseases, Alternaria leaf spot caused by Alternaria sp. are among the most destructive. Alternaria leaf blight alone reported to cause $100 \%$ yield loss in cucurbits caused by Alternaria cucumerina (Watt, Thamburaj and Singh (2001) described that the symptoms of Considering economic importance of the disease, the present investigation was undertaken. Alternaria blight and fruit rot of bottle gourd caused by A. cucumerina, where initial infect was :

\section{Materials and Methods}

\section{Isolation of the pathogen}

Direct tissue isolation technique was employed for the isolation of leaf spot associated pathogen from bottle gourd showing typical symptoms of leaf spot.

The samples collected from the field showing the infected leaf portion of actively progressing lesions were used for isolation on PDA media.

The infected leaf bits along with healthy portions were surface sterilized with 0.1 per cent sodium hypochloride solution for $60 \mathrm{sec}$ and washed repeatedly using sterilized distilled water.

Then they were aseptically transferred to potato dextrose agar slants and incubated at 25 $\pm 2{ }^{\circ} \mathrm{C}$ for eight days. The growth and sporulation of the fungus was monitored periodically. Further, purification and sub culture of this pathogen was done by following hyphal tip isolation.

\section{Proving pathogenicity}

The bottle gourd seedlings were raised by sowing healthy seeds in plastic pots, filled with sterilized soil. When plants were 25 days old, they were thoroughly cleaned with sterilized distilled water using moist cotton. Later inoculation to the leaves was done using spore suspension prepared from seven day old culture of Alternaria cucumerina in sterile distilled water. The leaves were covered with polythene bags to maintain sufficient humidity and to ensure successful penetration of the pathogen in to the host tissue. Control plants were maintained by atomizing sterile distilled water in the similar manner. Observations were made at regular intervals to know the symptom development on the inoculated leaves up to seven days. The fungus was re isolated and identified from the leaves showing characteristic disease symptoms to confirm the pathogenicity.

Re isolated the pathogen from the artificially inoculated plants and compared the cultures with the original culture to confirm the Koch's postulates and was used to evaluate the efficacy of fungicides.

\section{In vitro evaluation of fungicides and bioagents}

The efficacy of 15 selective fungicides namely with concentrations of 500,1000, 1500 ppm for systemic fungicides namely hexaconozole, tebuconozole, propiconozole, carbendazim, thiophenate methyl and 1500, 2000, 2500 ppm for contact and combination of fungicides namely Mancozeb, chlorothalonil, copper hydroxide, propineb, dithane Z-78, copper oxy chloride, captan, captan + hexaconozole, tebuconozole + trifloxystrobin, mancozeb + carbendazim was tested by following "poison food technique". Required quantities of individual fungicides were added into sterile molten potato dextrose agar to get the required 
concentration of different the fungicides on the basis of their weight. The efficacy of fungicides was expressed as per cent inhibition of radial growth over the control which was calculated by using the formula given by Vincent (1947).

$I=\frac{C-T}{C} \times 100$

Where, $\mathrm{I}=$ Per cent inhibition

$\mathrm{C}=$ Radial growth in control

$\mathrm{T}=$ Radial growth in treatment

Following bio agents were evaluated against the pathogen under in vitro by following dual culture plate technique.

\section{Results and Discussion}

Isolation of pathogens and proving pathogenicity.

Alternaria cucumerina was isolated from the infected leaf having necrotic lesions. The samples were then cut into small pieces having infected and healthy portion, surface sterilised with 0.1 per cent sodium hypochlorite solution for 60 seconds and then washed thoroughly for three times in sterile distilled water under aseptic conditions.

The samples were then placed aseptically in sterile Petri plates containing potato dextrose agar medium amended with suitable antibiotics such as streptomycin sulphate and incubated at $27 \pm 2^{0} \mathrm{C}$ for 8 days. The fungus pure culture was obtained by hyphal tip isolation as mentioned in material and methods Pure culture of pathogen were frequently (once in 15 days) subcultured on potato dextrose agar slants and maintained the cultures in the refrigerator for further studies.
Pathogenicity test was proved separately for Alternaria cucumerina on bottle gourd plants, pathogens were artificially inoculated on the leaves by spraying the spore suspension. For spore suspension spray method spores were harvested from one week old culture of pathogens in sterile distill water seperately from each pathogen. The spores are calculated using haemocytometer and mantained a concentration of $2 \times 10^{5}$ spores/ $\mathrm{ml}$. The bottle gourd plants were washed with sterile distill water and covered with polyethene covers one day prior to inoculation to create humidity. Then the spore suspension was sprayed uniformly on the leaves using hand sprayer and again covered with the polyethene covers and kept moistened with wet cotton swab to create humidity which helps for conidial germination. The typical symptoms of Alternaria leaf spot like initially small, circular brown coloured lesions with yellow halo appeared on older leaves. Later spots enlarged, became irregular in size. Spots coalesced to form big patches on leaves with a blighted symptoms (Plate 1).

The pathogen was reisolated from artificially inoculated leaves and the morphological characters of the reisolated organism were compared with the original culture of the pathogen and it was confirmed that the causal agent of the leaf spot was Alternaria cucumerina

\section{In vitro evaluation of fungicides against Alternaria cucumerina}

Fifteen fungicides were evaluated under in vitro by following poison food technique as described in material and methods and per cent inhibition of radial growth of Alternaria cucumerina by fungicides was recorded.

Table 1 and 2 reveals that among the fungicides tested, propiconazole gave maximum inhibition (100.00\%) of radial 
mycelial growth followed by hexaconazole, inhibition of 98.74, 95.42 and 94.78 per cent captan+ hexaconozole and tebuconozole + respectively. While the lowest inhibition was trifloxystrobin by recording mean per cent recorded in thiophenate methyl(38.02\%).

Table.1 List of biocontrol agaents used in vitro evaluation against Alternaria cucumerina

\begin{tabular}{|c|c|c|}
\hline Sl. No. & Bioagents & Source \\
\hline $\mathbf{1}$ & Trichoderma asperellum & UHSB product \\
\hline $\mathbf{2}$ & Trichoderma harzianum & UHSB product \\
\hline $\mathbf{3}$ & Pseudomonas fluorescens & UHSB product \\
\hline $\mathbf{4}$ & Bacillus subtilis & UHSB product \\
\hline
\end{tabular}

Table.2 In vitro evaluation of contact and combination fungicides against Alternaria cucumerina

\begin{tabular}{|c|c|c|c|c|c|}
\hline \multirow[t]{2}{*}{ Sl.No } & \multirow[t]{2}{*}{ Treatments } & \multicolumn{3}{|c|}{$\begin{array}{c}\text { Per cent inhibition of mycelia growth } \\
\text { Concentrations }\end{array}$} & \multirow{2}{*}{ Mean } \\
\hline & & $1500 \mathrm{ppm}$ & $2000 \mathrm{ppm}$ & $2500 \mathrm{ppm}$ & \\
\hline 1. & Captan $50 \mathrm{WP}$ & $\begin{array}{c}36.98 \\
(37.43)^{*}\end{array}$ & $\begin{array}{c}55.50 \\
(48.16)\end{array}$ & $\begin{array}{c}64.46 \\
(53.38)\end{array}$ & $\begin{array}{c}52.33 \\
(53.74)\end{array}$ \\
\hline 2. & Chlorothalonil $75 \mathrm{WP}$ & $\begin{array}{c}36.25 \\
(37.00)\end{array}$ & $\begin{array}{c}42.56 \\
(40.71)\end{array}$ & $\begin{array}{c}55.18 \\
(47.95)\end{array}$ & $\begin{array}{c}44.66 \\
(41.93)\end{array}$ \\
\hline 3. & Copper hydroxide $50 \mathrm{WP}$ & $\begin{array}{c}60.70 \\
(51.16)\end{array}$ & $\begin{array}{c}75.55 \\
(60.34)\end{array}$ & $\begin{array}{c}84.44 \\
(66.74)\end{array}$ & $\begin{array}{c}73.56 \\
(59.04)\end{array}$ \\
\hline 4. & Copper oxy chloride $50 \mathrm{WP}$ & $\begin{array}{c}41.11 \\
(39.86)\end{array}$ & $\begin{array}{c}67.35 \\
(55.13)\end{array}$ & $\begin{array}{l}78.14 \\
(62.12)\end{array}$ & $\begin{array}{c}62.20 \\
(51.88)\end{array}$ \\
\hline 5. & Dithane Z $7878 \mathrm{WP}$ & $\begin{array}{c}35.53 \\
(36.57)\end{array}$ & $\begin{array}{c}54.40 \\
(47.51)\end{array}$ & $\begin{array}{c}65.61 \\
(54.07)\end{array}$ & $\begin{array}{c}51.85 \\
(34.89)\end{array}$ \\
\hline 6. & Mancozeb 75 WP & $\begin{array}{c}75.53 \\
(60.33)\end{array}$ & $\begin{array}{l}100.00 \\
(90.00)\end{array}$ & $\begin{array}{l}100.00 \\
(90.00)\end{array}$ & $\begin{array}{c}91.84 \\
(73.38)\end{array}$ \\
\hline 7. & Propineb $70 \mathrm{WP}$ & $\begin{array}{c}53.91 \\
(47.22)\end{array}$ & $\begin{array}{c}74.79 \\
(59.85)\end{array}$ & $\begin{array}{c}96.21 \\
(78.79)\end{array}$ & $\begin{array}{c}74.97 \\
(60.14)\end{array}$ \\
\hline 8. & $\begin{array}{c}\text { Tebuconozole } 50 \%+\text { Trifloxystrobin } \\
25 \%\end{array}$ & $\begin{array}{c}91.11 \\
(72.64)\end{array}$ & $\begin{array}{c}94.78 \\
(76.97)\end{array}$ & $\begin{array}{c}98.43 \\
(82.86)\end{array}$ & $\begin{array}{c}94.78 \\
(76.78)\end{array}$ \\
\hline 9. & Carbendazim $12 \%+$ Mancozeb $63 \%$ & $\begin{array}{c}49.96 \\
(44.96)\end{array}$ & $\begin{array}{c}62.96 \\
(52.49)\end{array}$ & $\begin{array}{c}75.53 \\
(60.33)\end{array}$ & $\begin{array}{c}62.82 \\
(52.42)\end{array}$ \\
\hline 10. & Captan $70 \%+$ Hexaconozole $5 \%$ & $\begin{array}{c}86.26 \\
(68.26)\end{array}$ & $\begin{array}{l}100.00 \\
(90.00)\end{array}$ & $\begin{array}{l}100.00 \\
(90.00)\end{array}$ & $\begin{array}{c}95.42 \\
(76.31)\end{array}$ \\
\hline & Mean & $\begin{array}{c}51.57 \\
(45.89)\end{array}$ & $\begin{array}{c}66.18 \\
(54.39)\end{array}$ & $\begin{array}{c}74.36 \\
(59.54)\end{array}$ & \\
\hline \multicolumn{4}{|c|}{ Source } & S.E $\mathbf{m} \pm$ & CD@1\% \\
\hline \multicolumn{4}{|c|}{ Treatments } & 0.38 & 1.09 \\
\hline \multicolumn{4}{|c|}{ Concentration } & 0.20 & 0.57 \\
\hline \multicolumn{4}{|c|}{ Treatments x Concentration } & 0.67 & 1.89 \\
\hline
\end{tabular}


Table.3 In vitro evaluation of systemic fungicides against Alternaria cucumerina

\begin{tabular}{|c|c|c|c|c|c|}
\hline \multirow[t]{3}{*}{ Sl. No } & \multirow{3}{*}{ Treatments } & \multicolumn{4}{|c|}{ Per cent inhibition of mycelia growth } \\
\hline & & \multicolumn{4}{|c|}{ Concentrations } \\
\hline & & 500 ppm & $1000 \mathrm{ppm}$ & 1500 ppm & Mean \\
\hline 1. & Carbendazim $50 \mathrm{WP}$ & $\begin{array}{c}25.55 \\
(30.33) *\end{array}$ & $\begin{array}{l}40.74 \\
(39.65)\end{array}$ & $\begin{array}{c}56.66 \\
(48.81)\end{array}$ & $\begin{array}{l}40.98 \\
(39.79)\end{array}$ \\
\hline 2. & Hexaconozole 5 EC & $\begin{array}{c}96.23 \\
(78.95)\end{array}$ & $\begin{array}{l}100.00 \\
(90.00)\end{array}$ & $\begin{array}{l}100.00 \\
(90.00)\end{array}$ & $\begin{array}{c}98.74 \\
(80.75)\end{array}$ \\
\hline 3. & Propiconozole 25 EC & $\begin{array}{l}100.00 \\
(90.00)\end{array}$ & $\begin{array}{l}100.00 \\
(90.00)\end{array}$ & $\begin{array}{l}100.00 \\
(90.00)\end{array}$ & $\begin{array}{l}100.00 \\
(90.00)\end{array}$ \\
\hline 4. & Tebuconazole 250EC & $\begin{array}{c}76.29 \\
(60.85)\end{array}$ & $\begin{array}{l}100.00 \\
(90.00)\end{array}$ & $\begin{array}{l}100.00 \\
(90.00)\end{array}$ & $\begin{array}{c}92.09 \\
(86.00)\end{array}$ \\
\hline 5. & Thiophenate methyl $70 \mathrm{WP}$ & $\begin{array}{l}24.81 \\
(29.86)\end{array}$ & $\begin{array}{c}38.51 \\
(38.35)\end{array}$ & $\begin{array}{c}50.74 \\
(45.40)\end{array}$ & $\begin{array}{c}38.02 \\
(33.16)\end{array}$ \\
\hline & Mean & $\begin{array}{l}54.44 \\
(47.52)\end{array}$ & $\begin{array}{l}63.20 \\
(52.64)\end{array}$ & $\begin{array}{l}67.88 \\
(55.46)\end{array}$ & CD@1\% \\
\hline \multicolumn{4}{|c|}{ Source } & S.E $\mathbf{m} \pm$ & \\
\hline \multicolumn{4}{|c|}{ Treatments } & 0.36 & 1.05 \\
\hline \multicolumn{4}{|c|}{ Concentration } & 0.25 & 0.74 \\
\hline \multicolumn{4}{|c|}{ Treatments x Concentration } & 0.63 & 1.83 \\
\hline
\end{tabular}

* Figures presented in parenthesis are arc sine transformed value

Table.4 In vitro evaluation of bioagents against Alternaria cucurmerina

\begin{tabular}{|c|c|c|}
\hline Sl. No. & Bio agent & Per cent inhibition of mycelia growth \\
\hline $\mathbf{1}$ & Bacillus subtilis & 12.75 \\
& & $(20.89)^{*}$ \\
\hline $\mathbf{2}$ & Pseudomonas fluorescens & 20.16 \\
& & $(26.66)$ \\
\hline $\mathbf{3}$ & Trichoderma harzianum & 75.30 \\
& & $(60.18)$ \\
\hline $\mathbf{4}$ & Trichoderma asperellum & 72.42 \\
& & $(58.30)$ \\
\hline & S. Em \pm & $\mathbf{0 . 6 3}$ \\
\hline & CD @ $\mathbf{1 \%}$ & $\mathbf{2 . 0 3}$ \\
\hline
\end{tabular}

*Figures presented in parenthesis are arc sine transformed values 
Plate.1 In vitro evaluation of contact and combination fungicides against Alternaria cucumerina

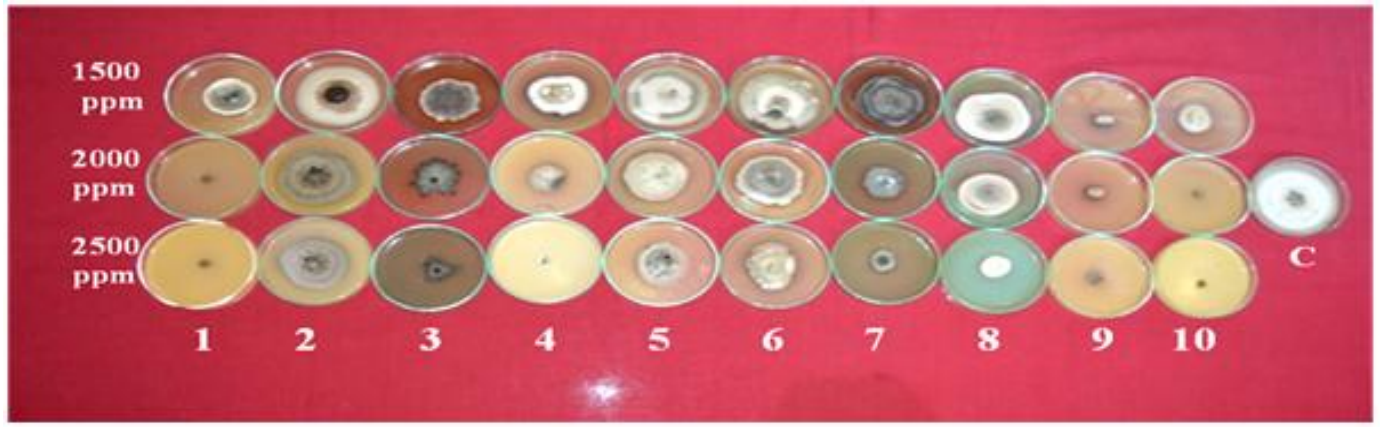

1.Mancozeb 2.Chlorothalonil 3.Copper hydroxide 4.Propineb 5 Captan, 6.Dithane Z 78 7.Copper oxy chloride 8.Mancozeb + Carbendazim 9.Captan + Hexaconozole 10.Tebuconozole + Trifloxystrobin C. Control

Plate.2 In vitro evaluation of systemic fungicides against Alternaria cucumerina

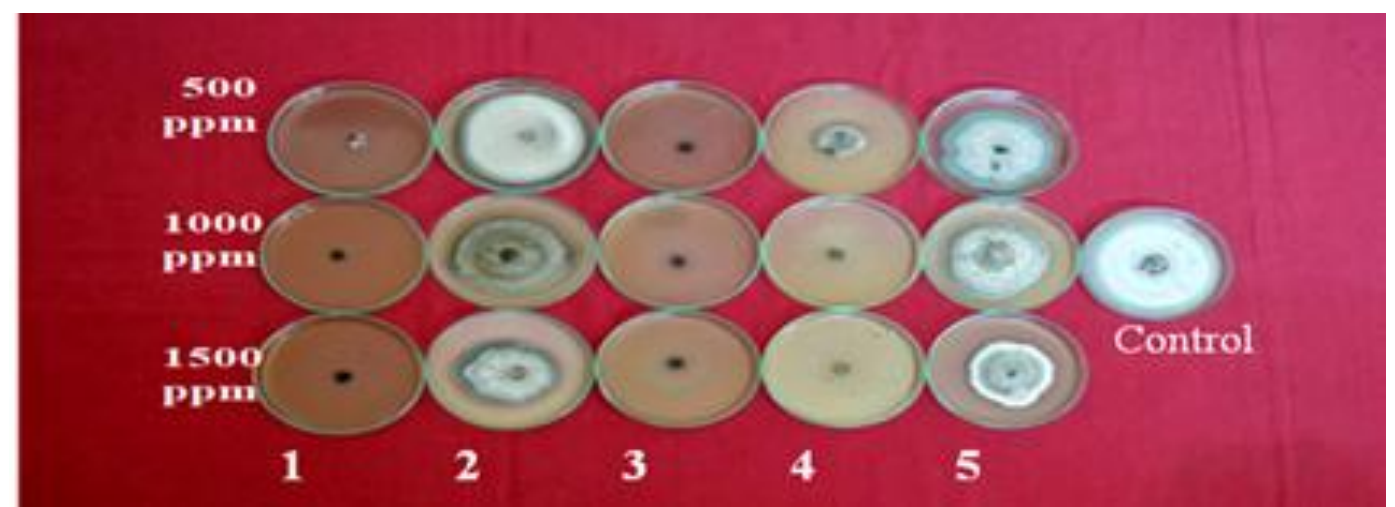

1. Hexaconozole 2.Thiophenate methyl 3.Propiconozole 4.Tebuconozole 5.Carbendazim

Plate.3 In vitro evaluation of bioagents against Alternaria cucumerina

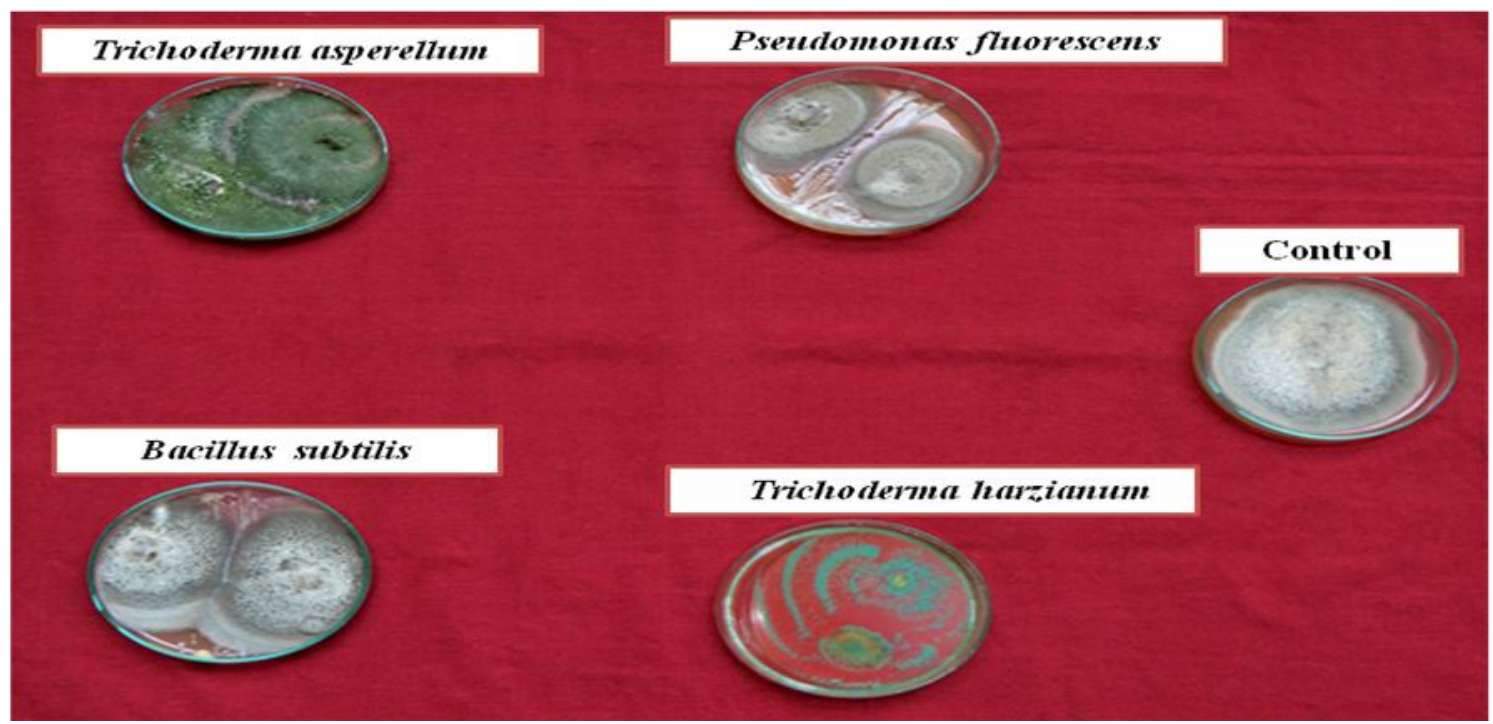


The results presented in Table 1 and Plate 1 revealed that among the contact and combination fungicides tested against $A$. cucumerina, at $1500 \mathrm{ppm}$, per cent inhibition was maximum in tebuconazole + trifloxystrobin (91.11 \%), followed by mancozeb (75.53 \%). At 2000 ppm mancozeb and captan + hexaconozole revealed 100 per cent inhibition which were on par with each other and significantly superior over other fungicides, followed by tebuconozole + trifloxystrobin $(94.78 \%)$ and copper hydroxide with $(75.55 \%)$. At 2500 ppm per cent inhibition was maximum in mancozeb and captan + hexaconozole with 100 per cent inhibition followed by tebuconozole + Trifloxystrobin and propineb with 98.43 and 96.21 per cent respectively. Chlorothalonil, captan and dithane Z 78 were least effective as recorded 55.18, 64.46 and 65.61per cent inhibition respectively at $2500 \mathrm{ppm}$ concentration.

Five systemic fungicides were evaluated at 500, 1000, 1500 ppm against A. cucumerina and recorded per cent inhibition of radial growth.

The results presented in the Table 2 and Plate 2 revealed that propiconozole recorded 100 per cent inhibition at all the concentrations tested. Hexaconozole and tebuconozole recorded 100 per cent inhibition at 1000 and $1500 \mathrm{ppm}$. Lowest mean inhibition was recorded in thiophenate methyl with 38.02 per cent, followed by carbendazim 40.98 per cent. These results were in agreement with the findings of Patel (2008), who reported that propiconozole at 250, 500 and $1000 \mathrm{ppm}$ and mancozeb at 2500 ppm showed 100 per cent inhibition of the mycelia growth of the Alternaria alternata. Identical results were obtained by Pawar and Sapkal (2014) and Prakash et al., (2017); where mancozeb (0.25 $\%$ ) was found most effective with 100 per cent inhibition of Alternaria alternata causing leaf spot in bottle gourd. The results were further supported by Sinha (2014) who reported that hexaconazole, propiconazole @ 0.025, 0.05 and $0.1 \%$ concentration completely inhibited $(100 \%)$ the growth of the pathogen. Among non-systemic fungicides, mancozeb and zineb @ $0.1,0.2$ and $0.3 \%$ concentration completely inhibited the growth of the pathogen. Efficacy of these fungicides were also reported by Viet et al., (2015).

Triazole antifungal agents inhibit the ergosterol biosynthesis pathway via the inhibition of 14- $\alpha$-demethylase, the enzyme that removes the methyl group at position $\mathrm{C}$ 14 of precursor sterols. Inhibition of this enzyme leads to the accumulation of aberrant sterol intermediates (1,4-- $\alpha$-methylsterols) on the fungal surface, which results in the arrest of the fungal growth. Mancozeb reacts with and inactivates the sulfhydryl groups of amino acids and enzymes within fungal cells, resulting in disruption of lipid metabolism, respiration and production of adenosine triphosphate.

The antagonistic activity of Bacillus subtilis, Pseudomonas fluorescens, Trichoderma asperellum, Trichoderma harzianum were assayed against the pathogens by dual plate technique as explained in material and methods. The results in the Table 3 and Plate 3 revealed that Trichoderma harzianum was most effective in inhibiting the mycelia growth of $A$. cucumerina with 75.30 per cent inhibition, followed by Trichoderma asperellum (72.42\%) inhibition. The least inhibition was observed in case of Bacillus subtilis with 12.75 per cent. The results were in agreement with the findings of Pareek et al.,(2012) who reported that Trichoderma harzianum was most effective over other treatments and produced inhibition zone of $7.40 \mathrm{~mm}$ followed by $T$ viride $(6.30 \mathrm{~mm})$ against Alternaria alternata. Similarly these results were in accordance with the findings of Viet et al.,(2015); Sinha (2014). 
Fifteen fungicides were tested under in vitro condition to know their efficacy against Alternaria cucumerina, propiconazole cent per cent inhibition of radial mycelial growth followed by hexaconazole, captan+ hexaconozole and tebuconozole + trifloxystrobin with mean per cent inhibition of $98.74,95.42$ and 94.78 respectively. While the lowest inhibition was recorded in thiophenate methyl (38.02\%).

\section{References}

Anonymous, 2017, Horticultural statistics at a glance,p. 286

Patel, K. M., 2008, Investigation on leaf spot [Alternaria alternata (Fr.) Keissler.of bitter gourd (Momordica charantia 1.) under south Gujarat condition. M.Sc. Thesis., N.A.U., Navsari.

Pawar.R. and Sapkal, R.T.,2014, Epidemiology, symptomatology and management of the fruit rot of bottle guord (Lagenaria siceraria) Bioscan., 9(1):363-370

Prakash,A.,Tulika. and Singh,A.,2017,Study on the impact of the selected contact and systemic fungicides on the mycelia growth of the Alternaria alternata in vitro. Indian J. Sci. Res., 17(1):314317.

Saha A, Das S, Chakraborty P, Saha B, Saha D (2016) Two New bottle gourd fruit rot causing pathogens from Sub Himalayan West Bengal. Int J Agri Biotech 12 (4): 707 - 719

Sinha, R. P., 2014, Occurrence, intensity and management of alternaria leaf spot disease of cabbage (Brassica oleracea var. capitata L.). M. Sc. Thesis, Birsa Agric. Univ. Ranchi, Jharkhand (India).

Thamburaj S, Singh N (2001) Cucurbitaceous vegetables Textbook of Vegetables, Tuber crops and Spices.p 271-319.

Viet, D. T., Somasekhara, M., Govindaraju, C., 2015,Evaluation of new molecules of fungicides against leaf spot (Alternaria brassicola (schw.) Wiltshire) of cabbage (Brassca oleracea var. capiata I.). Int. J. Agric. Sci. Res.5: 349-354.

Vincent J M (1947) Distortion of fungal hyphae in presence of certain inhihitors. Nature 150: 850

Zitter T A, Hopkins D L, Thomas C E (1998) Compendium of cucurbit Diseases. St Paul, Minn: APS Press.

\section{How to cite this article:}

Aishwarya S. Kammar, M. P. Basavarajappa, Raghavendra K. Mesta, S. H. Ramangouda and Shashikanth Evoor. 2019. In vitro Evaluation of Fungicides and Bioagents against Alternaria cucumerina (Ellis and Everh.) Elliott causing Alternaria Leaf Spot in Bottle Gourd. Int.J.Curr.Microbiol.App.Sci. 8(12): 2924-2931. doi: https://doi.org/10.20546/ijcmas.2019.812.339 